\title{
Conditional Effect of Foreign Aid on Production Efficiency in Developing Countries
}

\author{
Ruhaida Saidon * \\ Department of Economics and Agribusiness, School of Economics, Finance and Banking, Universiti Utara \\ Malaysia
}

\begin{abstract}
This study analyzes the conditional effect of foreign aid on production efficiency in selected 80 developing countries during the period of 2005-2017. This study involves parametric and non-parametric data analysis approach. The DEA (non-parametric) was used to get the production efficiency scores, while a panel Tobit regression analysis had conducted to measure the conditionality effect of foreign aid on the production efficiency. The results indicated that the conditional effect of foreign aid has a significant positive influence on production efficiency of developing countries during the period of study. This finding implies the positive impact of foreign aid on production efficiency depends on the conditional effect of foreign aid.
\end{abstract}

Keywords: Foreign Aid, Conditional Effect, Production Efficiency, Data Envelopment Analysis, Tobit Regression

JEL Classification: F35, Q01

Paper Type: Research

\section{INTRODUCTION}

Sustainable Development Goals 2030 (SDGs 2030) has targeted Sustainable consumption and production in Goal 12. This goal is about promoting resource and energy efficiency, sustainable infrastructure, and providing access to basic services, green and decent jobs and a better quality of life for all. Its implementation helps to achieve overall development plans, reduce future economic, environmental and social costs, strengthen economic competitiveness and reduce poverty. Therefore production efficiency becomes an important indicator to measure the achievement of Goal 12 of SDG. Production efficiency also represents the development of a country. Production efficiency reflects the production ability of a recipient country (Veiderpass and Andersson, 2007). The higher the production efficiency, the more efficient production inputs used in the production process.

Production efficiency and technological progress are the two components of total factor productivity (Grosskopf, 1993). Production efficiency is important for the aid recipient countries such as where its technological progress is slow. Technological

*Corresponding author: E-mail: ruhaida78@gmail.com 
progress is one of the major key determinants in improving production efficiency. Technological progress means the expansion of the set of production possibilities; an increase in production efficiency is synonymous to more efficient use of the existing production inputs and corresponds to a convergence towards the production frontier. However, developing countries typically have a lower rate of technological progress compared to developed countries. Therefore, foreign aid will be efficiently and increased production efficiency in the country.

However, Chen and Singh (2014) argued that foreign aid failed to increase production efficiency if it is being used unproductively such as unnecessary government expenditure, rent-seeking, corruption and excessive capital output. This finding supported by Hall and Jones (1999) when they indicate that differences between countries in capital accumulation, productivity, and output per worker ultimately attributed to differences in "social infrastructure," where they also defined it as "the institutions and government policies that determine the effectiveness of foreign aid on production efficiency. Studies by Feene and Roger (2008) stressed that the higher level of quality institutions and governance associated with higher production efficiency. While foreign aid increased production efficiency in democratic governance (Christopoulos et al., 2010), therefore, foreign aid will be efficiently and increased the production efficiency conditional with good quality of institutions. This study will investigate this conditional effect of sectoral allocation foreign aid on production efficiency.

\section{LITERATURE REVIEW}

Many kinds of literature on foreign aid has focused on its effectiveness in facilitating economic growth for recipient countries (Kanbur, 2006; Doucouliagos and Paldam, 2008). Most of the previous study focused on the direct effect of foreign aid to economic growth, poverty, inequality, human development and other social indicators. However, a few studies had examined the relationship between foreign aid and production efficiency. Veiderpass and Andersson (2007) examine the correlation between aid inflow and production efficiency of a country and using Data Envelopment Analysis (DEA) approach. They analyzed the performance of 60 countries between 1995 and 2000 and found that China, followed by Nigeria, displays the highest relative efficiency values over the period of study. India, Indonesia and Pakistan have the lowest efficiency index, which is between 14 and 15 per cent per year between 1995 and 2000. They found that labour and energyintensive countries had lower efficiency scores compared to less labour and energyintensive countries and positive relation between capital intensity and the country's production efficiency. However, they conclude that there is no clear pattern between the country's production efficiency and foreign aid.

In addition, Feeny and Rogers (2008) investigate the efficiency of public sector expenditures and foreign aid at achieving social sector outcomes in Small Island Developing States (SIDS). Efficiency is estimated using a Stochastic Production Function (SPF) approach and panel data since 1990. They also examine the determinants of efficiency in the second stage of the analysis. They found that the efficiency of aid and public sectors at improving life expectancy has deteriorated during the 1990s, but efficiency at improving school enrolments has increased. They conclude that higher levels of governance are associated with higher efficiency.

Christopoulos et al. (2010) used an endogenous growth model and employ empirical analysis using Stochastic Production Function (SPF) approach to investigate the link between foreign aid and production efficiency in the presence of different political orientations in the recipient country. Using a panel of 124 countries from 1971 to 2007 and the production frontier toolbox, controlling for unobserved heterogeneity, time horizons, 
the sources of aid, and the timing of aid impact, they document that foreign aid is associated with higher production inefficiency and that this inefficiency is considerably be reduced if countries switch to democratic governance.

Chen and Singh (2014) investigated foreign aid's impact on the Fijian economy using time series data for the period of 1980-2011. They used the method of two and threestage least squares to assess the foreign aid's impact on production efficiency. They found conclusive evidence that foreign aid and domestic factors are important in explaining output in Fiji. Christopoulos et al. (2016) were employed empirical analysis to investigate the link between foreign aid and production inefficiency in the presence of different political orientations in the recipient country. Our study contributes to the aid literature by pointing to the institutional enhancement of the recipient countries through the adoption of democratic rule.

In sum, this study makes significant contributions to the empirical literature on the impact of foreign aid on the production efficiency of the recipient countries. First, this study explores the impact of four main sectoral allocations of aid (social aid, economic aid, production aid and multi aid) on production efficiency. Second, this study attempts to include the interaction terms between four main sectoral allocations of foreign aid with quality institutions as a conditional factor in the analysis of the impact of foreign aid on production efficiency. Third, this study employs the panel Tobit regression to estimate the conditional effect of sectoral allocation of foreign aid on in enhancing production efficiency of selected foreign aid recipient countries.

\section{METHODOLOGY AND DATA}

\subsection{Data}

This study utilized a panel data set of 80 aid recipient countries for the period from 2005 to 2017. Based on the table, three variables are used in the DEA model to estimate production efficiencies. This study indicates GDP as the output of the DEA model, while gross capital formation and labour force as the input. The data of GDP, gross capital formation and labour force were sourced from World Development Indicator. The data of the sectoral allocation of aid (SAA) were downloaded from Organization of Economic Corporation and Development (OECD) in the Development Assistance Committee (DAC) under the Credit Reporting System (CRS). Finally, the quality of institutions index, law and order and socio-economic condition were compiled from ICRG.

\subsection{Model Specification}

The estimation of the impact of sectoral allocations of aid, quality of institutions and the interaction effect between these variables on production efficiency involved with two stages of analyses;

\section{First Stage: Estimating the efficiency score (production efficiency)}

The study employs the following two inputs - a single output production model:

$$
Y=f(K, L)
$$

where $Y$ is the output of the model, which is Gross Domestic Product (GDP), $K$ and $L$ denote as physical capital and labour. $K$ is proxies by gross capital formation as a 
percentage of GDP. This study uses DEA software (DEAP 2.1) to calculate the efficiency score from the above input and output specification model.

Second Stage: Estimating the impact of the sectoral allocation of aid and quality of institutions on the efficiency score (production efficiency)

The efficiency scores obtained from DEA in the first stage was used as a dependent variable in the second stage (using panel Tobit regression) and are regressed as the following model specification:

$$
S E=f(S A A, I N S, T O, S A A * I N S)
$$

$S E$ stands for scale efficiency, a proxy for production efficiency. The purpose of getting the efficiency score is to determine which type of efficiency score (pure technical efficiency or scale efficiency) that have a greater impact on technical efficiency. Scale efficiency is a major determinant of production efficiency in this study. Therefore, this study used scale efficiency scores to proxy production efficiency. SAA represents the four sectoral allocations of aid [social aid (SA), economic aid (EA), production aid (PA) and multi aid (MA)]. All these sectoral aids are expected to increase the production efficiency of the recipient countries. Thus the signs of these variables must be positive. INS represents the institution quality indicator proxies by law and order (LAO) and socioeconomic conditions (SEC) index. This indexed indicated that the higher score of these variables reflects a better quality of institutions. Based on this measurement, the coefficient of these variables must be positive. $S A A * I N S$ denotes as the interaction terms between the sectoral allocation of aid with law and order (LAO) and socioeconomic condition (SEC) index. These variables were used to capture the conditional effect of sectoral allocation foreign aid on production efficiency. The estimated coefficients of these variables are expected to have a positive sign. TO is defined as trade openness. Trade openness also one of the determinants of production efficiency. An increase in trade openness will cause an increase in production efficiency. Thus, the estimated coefficient of this variable must be positive.

This study estimates the production efficiency function as follows:

$$
\begin{aligned}
\theta_{\mathrm{i}, \mathrm{t}}=\alpha+\beta_{1} \ln S A_{\mathrm{i}, t} & +\beta_{2} \ln E A_{\mathrm{i}, \mathrm{t}} \\
& +\beta_{3} \ln P A_{\mathrm{i}, \mathrm{t}}+\beta_{4} \ln M A_{\mathrm{i}, \mathrm{t}}+\beta_{5} \ln T O_{\mathrm{i}, \mathrm{t}}+\beta_{\mathrm{6}} \ln L A O_{\mathrm{i}, \mathrm{t}}+\beta_{7}(\ln S A A * \ln L A O)_{\mathrm{i}, \mathrm{t}}+\varepsilon_{\mathrm{i}, \mathrm{t}}
\end{aligned}
$$

$$
\begin{aligned}
\theta_{\mathrm{i}, t}=\alpha+\beta_{1} \ln S A_{\mathrm{i}, t} & +\beta_{2} \ln E A_{\mathrm{i}, \mathrm{t}} \\
& +\beta_{\mathrm{a}} \ln P A_{\mathrm{i}, \mathrm{t}}+\beta_{4} \ln M A_{\mathrm{i}, \mathrm{t}}+\beta_{5} \ln T O_{\mathrm{i}, \mathrm{t}}+\beta_{\mathrm{6}} \ln S E C_{\mathrm{i}, \mathrm{t}}+\beta_{7}(\ln S A A * \ln S E C)_{\mathrm{i}, \mathrm{t}}+\varepsilon_{\mathrm{i}, \mathrm{t}}
\end{aligned}
$$

where $\theta_{i, t}$ is the scale efficiency (as a proxy for production efficiencies) of $i$ th of aid recipient country during the period 2005 to 2017.

In $(S A A)_{i, t}$ is the natural logarithm of the ratio of sectoral allocation of aid to GDP. It consists of four sectoral allocations of foreign aid: (a) natural logarithm of aid to social infrastructure and services sectors or social aid (In SA); (b) natural logarithm of aid to economic infrastructure and services sectors or economic aid (In $E A$ ); (c) natural logarithm of aid to production infrastructure and services sectors or production aid (In PA ), and (d) 
natural logarithm of aid to multi-infrastructure and services sector or multi-aid (In $(M A)$. This study assumes all sectoral allocations of aid have positive effects on production efficiency. In $(L A O)_{i, t}$ and In $(\mathrm{SEC})_{\mathrm{i}, \mathrm{t}}$ refer to institutional quality which proxies by law and order (LAO) and socioeconomic conditions (SEC) indices, respectively. The estimated coefficient of these variables is expected to be positive. In $(S A A * I N S)$ denotes the interaction terms of four sectoral allocations of foreign aid with LAO and SEC indices. The estimated coefficients of this variable are expected to have a positive sign.

\section{EMPIRICAL RESULTS}

Table 1 presents the empirical results of the effect of conditional factor (interaction term between the sectoral allocation of foreign aid and law and order and socio-economic condition) on production efficiency.

Table 1. Empirical Results

\begin{tabular}{|c|c|c|c|c|c|c|c|c|}
\hline \multirow[b]{2}{*}{$\begin{array}{c}\text { Appendix Alndepend } \\
\text { ent Variables }\end{array}$} & \multicolumn{8}{|c|}{ Dependent Variable: Production Efficiency (Scale Efficiency) } \\
\hline & $\begin{array}{l}\text { Model } \\
3 a \\
\left(S A^{*} \text { LA }\right. \\
0)\end{array}$ & $\begin{array}{l}\text { Model } \\
3 b \\
\left(E A^{*} \text { LA }\right. \\
O)\end{array}$ & $\begin{array}{l}\text { Model } \\
3 c \\
\left(P A^{*} L A\right. \\
0)\end{array}$ & $\begin{array}{l}\text { Model 3d } \\
\text { (MA*LA } \\
\text { O) }\end{array}$ & $\begin{array}{l}\text { Model } \\
4 a \\
\left(S A^{*} S E\right. \\
C)\end{array}$ & $\begin{array}{l}\text { Model } \\
4 \mathrm{~b} \\
\left(E A^{*} S E\right. \\
C)\end{array}$ & $\begin{array}{l}\text { Model } \\
4 \mathrm{C} \\
\left(\mathrm{PA}{ }^{*} \mathrm{SE}\right. \\
\mathrm{C})\end{array}$ & $\begin{array}{l}\text { Model 4d } \\
\left(M^{*} S E\right. \\
\text { C) }\end{array}$ \\
\hline Constant & $\begin{array}{l}-0.222 \\
(-0.92)\end{array}$ & $\begin{array}{l}-0.214 \\
(-0.89)\end{array}$ & $\begin{array}{l}-0.216 \\
(-0.89)\end{array}$ & $\begin{array}{l}-0.223 \\
(-0.92)\end{array}$ & $\begin{array}{l}-0.351 \\
(-1.44)\end{array}$ & $\begin{array}{l}-0.419^{*} \\
(-1.70)\end{array}$ & $\begin{array}{l}-0.346 \\
(-1.40)\end{array}$ & $\begin{array}{l}-0.274 \\
(-1.12)\end{array}$ \\
\hline Trade Openness & $\begin{array}{l}0.072^{* * *} \\
(2.61)\end{array}$ & $\begin{array}{l}0.070^{* *} \\
(2.54)\end{array}$ & $\begin{array}{l}0.071^{* *} \\
(2.59)\end{array}$ & $\begin{array}{l}0.073^{\star * *} \\
(2.62)\end{array}$ & $\begin{array}{l}0.094^{* * *} \\
(3.50)\end{array}$ & $\begin{array}{l}0.097^{* * *} \\
(3.58)\end{array}$ & $\begin{array}{l}0.093^{\star * *} \\
(3.44)\end{array}$ & $\begin{array}{l}0.088^{* * *} \\
(3.30)\end{array}$ \\
\hline Social aid (SA) & $\begin{array}{l}0.017 \\
(1.39)\end{array}$ & $\begin{array}{l}0.016 \\
(1.30)\end{array}$ & $\begin{array}{l}0.018 \\
(1.46)\end{array}$ & $\begin{array}{l}0.018 \\
(1.49)\end{array}$ & $\begin{array}{l}0.027^{* *} \\
(2.16)\end{array}$ & $\begin{array}{l}0.027^{* *} \\
(2.26)\end{array}$ & $\begin{array}{l}0.025^{* *} \\
(2.06)\end{array}$ & $\begin{array}{l}0.022^{*} \\
(1.85)\end{array}$ \\
\hline Economic aid (EA) & $\begin{array}{l}0.013^{* *} \\
(2.58)\end{array}$ & $\begin{array}{l}0.014^{* * *} \\
(2.88)\end{array}$ & $\begin{array}{l}0.012^{* *} \\
(2.53)\end{array}$ & $\begin{array}{l}0.012^{* *} \\
(2.53)\end{array}$ & $\begin{array}{l}0.012^{* *} \\
(2.55)\end{array}$ & $\begin{array}{l}0.011^{* *} \\
(2.41)\end{array}$ & $\begin{array}{l}0.012^{* *} \\
(2.45)\end{array}$ & $\begin{array}{l}0.014^{* * *} \\
(2.88)\end{array}$ \\
\hline Production aid (PA) & $\begin{array}{l}0.010 \\
(1.44)\end{array}$ & $\begin{array}{l}0.011^{*} \\
(1.66)\end{array}$ & $\begin{array}{l}0.010 \\
(1.26)\end{array}$ & $\begin{array}{l}0.009 \\
(1.41)\end{array}$ & $\begin{array}{l}-0.002 \\
(-0.27)\end{array}$ & $\begin{array}{l}0.001 \\
(0.08)\end{array}$ & $\begin{array}{l}0.0004 \\
(0.06)\end{array}$ & $\begin{array}{l}0.0004 \\
(0.06)\end{array}$ \\
\hline Multi aid (MA) & $\begin{array}{l}0.006 \\
(0.71)\end{array}$ & $\begin{array}{l}0.005 \\
(0.51)\end{array}$ & $\begin{array}{l}0.006 \\
(0.73)\end{array}$ & $\begin{array}{l}0.005 \\
(0.61)\end{array}$ & $\begin{array}{l}0.010 \\
(1.16)\end{array}$ & $\begin{array}{l}0.012 \\
(1.41)\end{array}$ & $\begin{array}{l}0.011 \\
(1.31)\end{array}$ & $\begin{array}{l}0.006 \\
(0.77)\end{array}$ \\
\hline Law and order (LAO) & $\begin{array}{l}0.048^{* *} \\
(2.02)\end{array}$ & $\begin{array}{l}0.057^{* *} \\
(2.39)\end{array}$ & $\begin{array}{l}0.047^{* *} \\
(2.00)\end{array}$ & $\begin{array}{l}0.047^{* *} \\
(1.98)\end{array}$ & - & - & - & - \\
\hline SAA x LAO & $\begin{array}{l}0.010 \\
(0.39)\end{array}$ & $\begin{array}{l}0.021^{* *} \\
(2.07)\end{array}$ & $\begin{array}{l}-0.003 \\
(-0.24)\end{array}$ & $\begin{array}{l}-0.007 \\
(-0.39)\end{array}$ & - & - & - & - \\
\hline $\begin{array}{l}\text { Socioeconomic } \\
\text { Condition (SEC) }\end{array}$ & - & - & - & - & $\begin{array}{l}0.042 \\
(1.10)\end{array}$ & $\begin{array}{l}0.041 \\
(1.05)\end{array}$ & $\begin{array}{l}0.035 \\
(0.90)\end{array}$ & $\begin{array}{l}0.047 \\
(1.23)\end{array}$ \\
\hline SAA $\times$ SEC & - & - & - & - & $\begin{array}{l}- \\
0.053^{* * *} \\
(-2.78)\end{array}$ & $\begin{array}{l}-0.012 \\
(-1.32)\end{array}$ & $\begin{array}{l}-0.010 \\
(-0.89)\end{array}$ & $\begin{array}{l}-0.046^{* * *} \\
(-2.76)\end{array}$ \\
\hline Sigma_u & $\begin{array}{l}0.201^{* * *} \\
(10.37)\end{array}$ & $\begin{array}{l}0.201^{* * *} \\
(10.43)\end{array}$ & $\begin{array}{l}0.200^{* * *} \\
(10.37)\end{array}$ & $\begin{array}{l}0.200^{\star * *} \\
(10.40)\end{array}$ & $\begin{array}{l}0.192^{* * *} \\
(9.71)\end{array}$ & 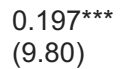 & $\begin{array}{l}0.198^{\star \star *} \\
(9.78)\end{array}$ & $\begin{array}{l}0.191^{* * *} \\
(9.74)\end{array}$ \\
\hline Sigma_e & $\begin{array}{l}0.046^{\star * *} \\
(20.21)\end{array}$ & $\begin{array}{l}0.046^{\star * *} \\
(20.24)\end{array}$ & $\begin{array}{l}0.046^{\star * *} \\
(20.21)\end{array}$ & $\begin{array}{l}0.046^{\star * *} \\
(20.23)\end{array}$ & $\begin{array}{l}0.044^{* * *} \\
(19.57)\end{array}$ & $\begin{array}{l}0.044^{* * *} \\
(19.62)\end{array}$ & $\begin{array}{l}0.044^{* * *} \\
(19.61)\end{array}$ & $\begin{array}{l}0.044^{* * *} \\
(19.59)\end{array}$ \\
\hline Rho & $\begin{array}{l}0.949 \\
(0.010)\end{array}$ & $\begin{array}{l}0.949 \\
(0.010)\end{array}$ & $\begin{array}{l}0.948 \\
(0.010)\end{array}$ & $\begin{array}{l}0.948 \\
(0.010)\end{array}$ & $\begin{array}{l}0.949 \\
(0.011)^{a}\end{array}$ & $\begin{array}{l}0.951 \\
(0.010)^{a}\end{array}$ & $\begin{array}{l}0.951 \\
(0.010)^{a}\end{array}$ & $\begin{array}{l}0.948 \\
(0.011)^{a}\end{array}$ \\
\hline Log Likelihood & 309.96 & 312.01 & 309.91 & 309.96 & 311.14 & 309.46 & 308.99 & 312.41 \\
\hline Wald test & $\begin{array}{l}31.87 \\
(0.000)\end{array}$ & $\begin{array}{l}36.51 \\
(0.000)\end{array}$ & $\begin{array}{l}31.76 \\
(0.000)\end{array}$ & $\begin{array}{l}31.86 \\
(0.000)\end{array}$ & $\begin{array}{l}37.28 \\
(0.000)\end{array}$ & $\begin{array}{l}33.46 \\
(0.000)\end{array}$ & $\begin{array}{l}32.46 \\
(0.000)\end{array}$ & $\begin{array}{l}40.23 \\
(0.000)\end{array}$ \\
\hline No. of observations & 267 & 267 & 267 & 267 & 258 & 258 & 258 & 258 \\
\hline
\end{tabular}

The empirical findings in Model $3 a$ to $3 \mathrm{~d}$ depicted that the estimated coefficient of trade openness, economic aid, law and order and the interaction variable of economic aid and law and order had positive and statistically significant affected production efficiency at least at 5 percent. Meanwhile, the estimated coefficient of trade openness, economic aid and social aid had shown in Model $4 a$ to $4 b$ had shown positive and statistically significant affected production efficiency at least at 5 percent. However, the estimated coefficient of 
socioeconomic condition was found to have an insignificant effect on production efficiency. Most importantly, the coefficient of the interaction variable of social aid and multi aid with the socioeconomic condition had a negative and statistically significant effect on production efficiency at 1 percent. The findings supported the arguments by Feene and Roger (2008) and Christopoulos et al. (2010, 2016) and Chen and Singh (2014) the effect of foreign aid on production efficiency depended on its conditional factor. Institutional quality was a conditional factor of the effects of sectoral allocation of foreign aid on production efficiency.

\section{CONCLUSION}

This paper examined the conditional effect of foreign aid on production efficiency production of 80 aid recipient countries during the period 2005-2017. The production efficiency of the individual countries was evaluated using the non-parametric DEA approach. While the parametric approach, Tobit regression was conducted to investigate the effect of sectoral foreign aid (social aid, economic aid, production aid and multi aid) conditional with institutional quality (law and order and socio-economic condition) on affecting production efficiency. The findings of this study suggested that institutional quality was a conditional factor to the effects of sectoral allocations of foreign aid on production efficiency in aid recipient countries. In conclusion, the positive effect of sectoral allocation of foreign depends on the good institutional quality.

\section{REFERENCES}

Chen, H., \& Singh, B. (2014). Foreign aid and labor productivity in Fiji: an empirical investigation within an endogenous production framework. International Journal of Applied Economics, 11(1), 60-77.

Christopoulos, D., Siouronis, G. \& Vlachaki, I. (2010). Democratic reforms, foreign aid and production efficiency. MPRA Working Papers No. 23607. University Liabrary of Munich, Germany.

Christopoulos, D. K., Siourounis, G., \& Vlachaki, I. (2016). Democratic Reforms, Foreign Aid and Production Inefficiency. The Manchester School, 84(3), 363-389.

Doucouliagos, H., \& Paldam, M. (2008). Aid effectiveness on growth: A meta study. European Journal of Political Economy, 24(1), 1-24.

Feeny, S., \& Rogers, M. (2008). Public sector efficiency, foreign aid and small island developing states. Journal of International Development, 20 (4), 526-546.

Grosskopf, S. (1993). Efficiency and productivity. The Measurement of Productive Efficiency: Techniques and Applications, 160-194.

Hall, R. E., \& Jones, C. I. (1999). Why do some countries produce so much more output per worker than others?. The Quarterly Journal of Economics, 114(1), 83-116.

Kanbur, R. (2006). The economics of international aid. Handbook of the economics of giving, altruism and reciprocity, 2, 1559-1588.

Organization for Economic Co-operation and Development (OECD). (n.d.a). Aid statistics. Official development assistance - definition and coverage, Available Online: http://www.oecd.org/dac/stats/officialdevelopmentassistancedefinitionandcoverage.htm\#Definition [Accessed 30th November 2017]

Organization for Economic Co-operation and Development (OECD). (n.d.b). CPA data series by sector, Available Online: http://www.oecd.org/development/aid-architecture/cpa.htm [Accessed 30th November 2013]

Organization for Economic Co-operation and Development (OECD).(n.d.c). Development Co-operation Directorate (DCD-DAC). DAC members, Available Online: http://www.oecd.org/dac/dacmembers.htm [Accessed 30th November 2017]

Organization for Economic Co-operation and Development (OECD). (n.d.d). The Paris Declaration on Aid Effectiveness and the Accra Agenda for Action [pdf] Available Online: http://www.oecd.org/dac/effectiveness/parisdeclarationandaccraagendaforactionfullrelateddocumentato n.htm [Accessed 11th November 2017]

Organization for Economic Co-operation and Development (OECD), Query Wizard for International Development Statistics. (n.d.e). QWIDS data query, Available Online: http://stats.oecd.org/qwids/ [Accessed 2 December 2013] 
Conditional Effect of Foreign Aid on Production Efficiency in Developing Countries

Veiderpass, A., \& Andersson, P. (2007). Foreign aid, economic growth and efficiency development. Swedish Agency for Development Evaluation. 